\title{
THE EFFECT OF VARIOUS DESENSITIZING AGENT APPLICATION ON IN-OFFICE BLEACHING ON THE NUMBER OF FIBROBLASTS
}

Nunik Rahayu Apriliyani*, Ema Mulyawati*, Yulita Kristanti*

* Universitas Gadjah Mada

Correspondence : nunikrahayu@mail.ugm.ac.id

\section{Keywords: \\ desensitizing agent, in- office bleaching, number of fibroblasts}

\begin{abstract}
Background: Reactive Oxygen Species (ROS) released from hydrogen peroxide causes inflammation of the pulp. Remineralization action by fluoridecontaining desensitizing agent (Casein Phosphopeptides-Amorphous Calcium Fluoride Phosphate/CPP-ACFP) occluding dentinal tubule, thereby minimizing the penetration of hydrogen peroxide into the pulp and affect the number of fibroblasts. The aim of this study was to determine the effect of fluoridecontaining desensitizing agent (CPP-ACFP) application: before, after, and before-after in-office bleaching techniques using $40 \%$ hydrogen peroxide on the number of fibroblasts.

Method: Twenty-eight maxillary molar teeth were divided into 4 groups, Control Group (bleaching treatment), Group I (CPP-ACFP application before bleaching), Group II (CPP-ACFP application after bleaching), and Group III (CPP-ACFP application before and after bleaching). Rats were sacrificed 5 days after and histological preparations were stained with HE. Fibroblasts counting was performed using a 1000x magnification light microscope.

Result: ANOVA test showed that there were significant mean differences in the number of fibroblasts among the groups. The LSD test showed that there were statistically significant differences in almost all of the compared groups except between the Control Group and Group II.

Conclusion: The number of fibroblasts in the pulp of rats applied CPP-ACFP before and after in-office bleaching was less than applied CPP-ACFP before or after in-office bleaching.
\end{abstract}

\section{INTRODUCTION}

In-office bleaching is a bleaching technique using high concentrations of hydrogen peroxide and has several advantages, for instance the treatment process is very fast and the process is controlled by the dentist, thus the results can be seen in one visit and the patient is more cooperative ${ }^{1,2}$. Hydrogen peroxide as an active bleaching agent is an oxidant, with the help of chemical or physical activators it breaks down into hydroxyl radicals, perhydroxyl radicals, perhydroxyls anions and superoxide anions. These reactive free radicals have a low molecular weight (34 daltons) which accelerates their diffusion to the enamel prism and interprismatic space, as well as through the dentin organic matrix ${ }^{1,3,4}$. The higher the concentration and application time of hydrogen peroxide, the higher the oxidative stress produced on the pulp because the deeper the penetration through enamel and dentin and the more Reactive Oxygen Species (ROS) produced ${ }^{5,6}$.

The loss of some minerals in enamel and dentin has a positive correlation with increased porosity which facilitates the diffusion of the bleaching agent into the dentin and pulp 
structures. To overcome mineral loss and its effects, it is recommended to use desensitizing agents that can induce remineralization? ${ }^{7}$. Based on the way it works, there are 2 kinds of desensitizing agents, namely those that work by means of nerve blockade and those that work by closing the dentinal tubules. Desensitizing agents act by covering the dentinal tubules by the formation of insoluble precipitates (i. e. oxalate crystals, calcium phosphate crystals, fluorine phosphate crystals). The decrease in dentin permeability that occurs due to partial closure of the tubules, causes the movement of fluid in the dentinal tubules to decrease $e^{8,9,10}$.

Calcium Phosphopeptide-Amorphous Calcium Phosphate (CPP-ACFP) is a desensitizing agent that form calcium phosphate precipitates in the exposed dentinal tubules resulting in partial closure of the dentinal tubules ${ }^{11,12,13}$. Research by Kristanti et al,using XRay Diffraction proved that when CPP-ACFP was applied before and after in-office bleaching showed the least mineral loss compared to the control group and the group that applied CPP. ACFP before or after the in-office bleaching only ${ }^{14}$.

Fibroblasts are located towards the center of the pulp and play a role in the formation and replacement of the extracellular matrix of the pulp $^{15}$. Fibroblasts are oval-shaped, large, and pale cells, with a clearly visible nucleus, and have many irregular cytoplasmic branches. These cells play a role in the pulp-dentin regeneration 16,17 . There are two types of fibroblasts, active fibroblasts and passive fibroblasts. The presence of active fibroblasts is an indicator of fibroblast proliferation activity ${ }^{18,19}$. In physiological conditions, fibroblasts have a low proliferation index and metabolic activity, while during the healing process fibroblasts have high proliferation and metabolic rates ${ }^{17}$. Fibroblasts play a role by producing various inflammatory mediators such as IL-8, IL-6, and Vascular Endothelial Growth Factor (VEGF) and initiating the formation of reparative dentin ${ }^{20}$. Fibroblasts migrate to the injured area and differentiate into odontoblast-like-cells to initiate reparative dentin formation as an effort to heal tissue ${ }^{21,22}$. In the wound healing process, fibroblasts play a role in the proliferation phase. Fibroblasts maintain the integrity of connective tissue in the pulp by synthesizing collagen types I and III, as well as proteoglycans and glycosaminoglycans, which are also responsible for collagen turnover because they have the ability to phagocytosis and digest collagen ${ }^{23}$.

The aim of this study was to determine the effect of variations of fluoride containing desensitizing agent (CPP-ACFP) application: before, after and before-after in-office bleaching techniques using $40 \%$ hydrogen peroxide on the number of fibroblasts.

\section{METHODS}

This research protocol was approved by the Ethics and Advocacy Unit (No. 00444/KKEP/FKG-UGM/EC/2020) of the Faculty of Dentistry, Gadjah Mada University (Yogyakarta, Indonesia).

The male Wistar rats were anesthetized by intramuscular injection of ketamine-xylazine (40 mg/kg). The upper left and right molar teeth of rats were assigned to 4 groups. In the control group, $0.01 \mathrm{ml}$ of $40 \%$ hydrogen peroxide (Opalescence Boost PF 40\%, Ultradent, USA) was applied to the occlusal surface for 5 minutes then cleaned with an aspiration tip and rinsed with distilled water. Group I, $0.1 \mathrm{ml}$ Casein Phosphopeptide-Amorphous Calcium Fluoride Phosphate (CPP-ACFP) (Tooth Mousse Plus®, GC) was applied for 3 minutes on the occlusal surface then cleaned with a cotton bud followed by 
application of $0.01 \mathrm{ml}$ of $40 \%$ hydrogen peroxide for 5 minutes then cleaned with an aspiration tip and rinsed with distilled water. Groups II and III received the same treatment as Group I, but in Group II CPP-ACFP was applied after 40\% hydrogen peroxide application, whereas in Group III CPP-ACFP was applied before and after $40 \%$ hydrogen peroxide application. Five days after the treatment, the rats were killed with a lethal dose of ketamine $\mathrm{HCl}(0,2 \mathrm{ml} / 250 \mathrm{gram})$. The right and left maxillae from each rat were separated, dissected, and fixed in a solution of $10 \%$ buffered formalin for 24 hours. The tissues were then dehydrated through a graded series of ethanol and embedded in paraffin blocks. All of these stages were done by the previous researcher ${ }^{24}$.

In this study, there were 28 upper molar paraffin blocks of male Wistar rats consisted of 4 groups $(n=7)$. Four-micron sections were cut in the mesiosagittal plane using a microtome (Sakura Accu-cut SRM Microtome, Japan), and stained with Hematoxylin Eosin using an Automatic Staining Machine (Thermo Scientific, USA). Observations by 3 observers were performed under light microscope (1000x, Olympus CX 33, Japan) equipped with a microscope camera (Sigma, USA). The observed fibroblasts consisted of active fibroblasts and passive fibroblasts. Active fibroblasts have a relatively large cytoplasm, round, long, blunt, and sometimes branched, oval-shaped nucleus. Passive fibroblasts are smaller than active fibroblasts, are coil-shaped, with an elongated process and a darker, more heterochromatic ovalshaped ${ }^{18,19}$. The calculations were performed in three fields of view in the coronal pulp with a "V" pattern (Figure 1). The number of accumulated fibroblasts is then divided by 3 according to the number of fields of view ${ }^{16}$. Data were analyzed using ANOVA followed by LSD.

\section{RESULTS}

The data obtained in this study were ratio data, namely the number of fibroblasts. The image of fibroblasts in rat pulp can be seen in Figure 2 . The data are the results of the mean calculation of the number of fibroblasts divided by the number of fields of view observed by 3 observers. The mean results were tested for reliability by using the Pearson correlation test then the data were analyzed by using the Shapiro-Wilk normality test to determine the distribution of the data, meanwhile the homogeneity test of variance using the Levene test.

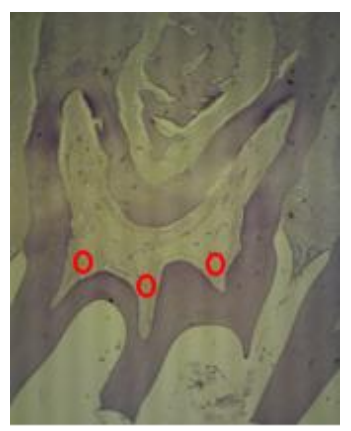

Figure 1. Illustration of fields of view in the coronal pulp with a "V" pattern.

Tabel 1. Time eruption primary teeth ${ }^{5}$

\begin{tabular}{ccccc}
\multicolumn{2}{c}{ Tooth } & Seed Formation & Eruption & Grow Perfectly \\
\hline Upper Jaw & Insisivus 1 & 4 months & 7,5 months & 1,5 years old \\
\cline { 2 - 4 }
\end{tabular}




\begin{tabular}{llccc}
\cline { 2 - 5 } & Insisivus 2 & 4,5 months & 9 months & 2 years old \\
\cline { 2 - 5 } & Caninus & 5 months & 18 months & 3,5 years old \\
\cline { 2 - 5 } Molar 1 & 5 months & 14 months & 2,5 years old \\
\cline { 2 - 5 } Lower Jaw & Molar 2 & 6 months & 24 months & 3 years old \\
\cline { 2 - 5 } & Insisivus 1 & 4,5 months & 7 months & 1,5 years old \\
\cline { 2 - 5 } & Insisivus 2 & 4,5 months & 7 months & 1,5 years old \\
\cline { 2 - 5 } & Caninus & 5 months & 16 months & 3,5 years old \\
\cline { 2 - 5 } & Molar 1 & 3 months & 12 months & 2,5 years old \\
\cline { 2 - 5 } & Molar 2 & 6 months & 20 months & 3 years old
\end{tabular}

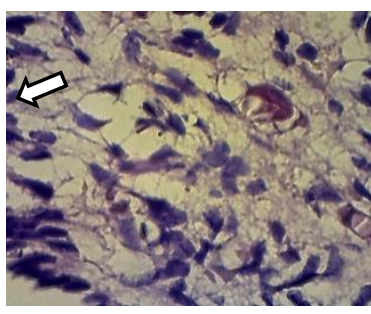

(a)

Control Group

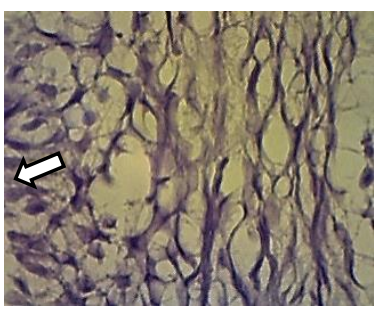

(c)

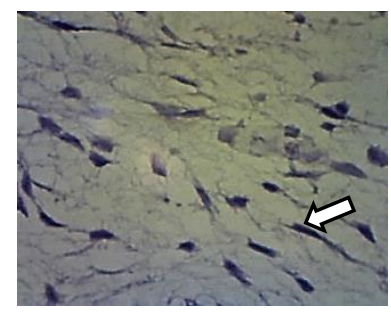

(b)

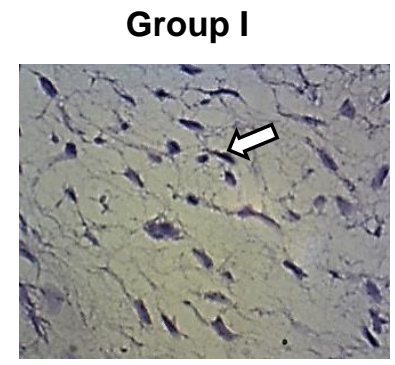

(d)

Figure 2. Representative images of specimens at 1000x magnification in the Control Group (a), Group I (b), Group II (c), and Group III (d). Fibroblasts are indicated by white arrows.

Table 1. The mean and standard deviation of the effect of various fluoride containing desensitizing agent application related to in-office bleaching using $40 \%$ hydrogen peroxide on the number of fibroblasts

\begin{tabular}{cc} 
Group & Mean \pm SD \\
\hline Control & $18,614 \pm 1,8872$ \\
\hline Group I & $13,200 \pm 1,6643$ \\
\hline Group II & $17,486 \pm 2,1162$ \\
\hline Group III & $11,157 \pm 1,4604$
\end{tabular}

Table 2. A one-way ANOVA of the effect of fluoride containing desensitizing agent application related to inoffice bleaching using $40 \%$ hydrogen peroxide on the number of fibroblasts

\begin{tabular}{lrrrrr} 
& Sum of Squares & df & Mean Square & F & p \\
\hline Between Groups & 260,380 & 3 & 86,793 & 26,825 & $0,000^{*}$ \\
\hline Within Groups & 77,654 & 24 & 3,236 & & \\
\hline Total & 338,034 & 27 & & & \\
\hline
\end{tabular}

Table 3. LSD test of the number of fibroblasts between Control Group, Group I (CPP-ACFP application before in-office bleaching), group II (CPP-ACFP application after in-office bleaching), and group III (CPP-

ACFP application before and after in-office bleaching)

Comparison groups Control
LSD

Group I $5,4143 \quad 0,000^{*}$




\begin{tabular}{llrr} 
& Group II & 1,1286 & 0,252 \\
\cline { 2 - 4 } Group I & Group III & 7,4571 & $0,000^{*}$ \\
\cline { 2 - 4 } & Group II & $-4,2857$ & $0,000^{*}$ \\
\cline { 2 - 4 } Group II & Group III & 2,0429 & $0,044^{*}$ \\
\cline { 2 - 4 } & Group III & 6,3286 & $0,000^{*}$ \\
\hline
\end{tabular}

\section{DISCUSSION}

This research used Wistar rats because they have a physiological system and inflammatory reactions that resemble humans, are easy to handle, easy to standardize and control, and relatively economical ${ }^{25,26}$. Upper molar teeth were chosen because the structure and anatomical shape of these rats resembled human molar teeth 27,28 .

The tissue specimens taken 5 days after treatment (application of $40 \%$ hydrogen peroxide bleaching agent with three variations of the application of Casein Phosphopeptide-Amorphous Calcium Fluoride Phosphate (CPP-ACFP)). This is consistent with the statement of Vellnar et al. (2009) cit. Pribadi29 (2017) stated that the proliferative phase starts on the third day to two weeks after injury. The proliferative phase is characterized by the formation of granulation tissue in the lesion area by cells that play an important role, namely fibroblasts ${ }^{30}$.

Migration and proliferation of fibroblasts marked the start of a proliferative phase in wound healing, beginning in the final inflammatory phase by secreting growth factors, cytokines, collagen, and other components of the extracellular matrix ${ }^{31}$. Migration of undifferentiated stem cells and fibroblasts to the injured area occurs from the $3^{\text {rd }}$ day and reaches a peak on the $7^{\text {th }}$ day. This action is stimulated by several cytokines (i.e. fibroblast growth factor/FGF, insulin-like growth factor1/IGF-1, and platelet-derived growth factor/PDGF) which were initially produced by platelets but were subsequently produced by macrophages and lymphocytes ${ }^{30}$.

Demineralization that is caused as a side effect of bleaching can affect the content of calcium and phosphate ions. In enamel, the phenomena detected were a decrease in hardness and an increase in surface roughness. In dentin, hydrogen peroxide causes oxidation of organic components resulting in an increase in the diameter of the dentinal tubules, because peritubular dentin, which contains more minerals and less collagen, is more resistant to hydrogen peroxide than intertubular dentine which contains more collagen. This can lead to increased dentin permeability ${ }^{14,32,33,34}$. Hydrogen peroxide as an active ingredient in in-office bleaching is a strong oxidant that can break down into free radicals (Reactive Oxygen Species/ROS) ${ }^{35}$. Reactive Oxygen Species (ROS), which are chemical irritants that cause inflammation of the pulp, are marked by an increase in blood vessel dilation, the number of macrophages, and the intensity of the inflammatory response ${ }^{36}$. Reactive Oxygen Species (ROS) are reactive species that contain oxygen, some have unpaired electrons and are included in the free radical category such as super oxidants and hydroxyl, there are also ROS that does not have unpaired electrons (unpaired electrons) and is called non-radical derivatives of molecular oxygen, for example, hydrogen peroxide $^{37}$. Reactive Oxygen Species can induce oxidative stress in pulp tissue if there is an 
imbalance between the amount of ROS and antioxidants ${ }^{29,39}$.

The desensitizing agent is a material used to minimize the effects of bleaching agents, one of which is Casein Phosphopeptide-Amorphous Calcium Fluoride Phosphate (CPP-ACFP) which also has a remineralization effect. Amorphous Calcium Phosphate can break down into calcium and phosphate ions causing remineralization by forming fluorapatite precipitates and closing the dentinal tubules ${ }^{40,41}$.

The results of the one-way Anava test showed that there was a significant difference ( $p$ $<0.005$ ) in the effect of variations in the application of CPP-ACFP between groups, which means that variations in the application of desensitizing agent containing fluorine in in-office bleaching with $40 \%$ hydrogen peroxide affected on the number of fibroblasts.

The results of the Least Significant Difference (LSD) test on the mean number of fibroblasts showed a significant difference in the mean number of fibroblasts between the Control group and Group I and between the Control group and Group III. In the control group that did not apply CPP-ACFP, it was seen that the number of fibroblasts detected was more than those in Group I and Group III. The effects of bleaching on enamel and dentin include loss of minerals, increased porosity, and increased diameter of the dentinal tubules, thereby facilitating the diffusion of the bleaching material and its products (ROS) to the pulp. The more bleaching agents that can pass through the enamel and dentin to the pulp, the more potential for pulp injury due to oxidative stress increases so that the highest number of fibroblasts is detected.

Oxidative stress is a situation in which the stationary concentration of ROS increases temporarily or chronically, exceeding the defense capacity of the antioxidant. This condition has the potential to cause tissue injury because it triggers hypoxia which leads to ischemia which can affect the biological system 38,42. High levels of ROS cause damage to lipids, proteins, and DNA 26,42 .

Odontoblast damage due to the bleaching effect causes the formation of dead tracts which facilitate the penetration of chemicals into the pulp, which causes activated fibroblasts ${ }^{14,17}$. Goldberg and Hirata ${ }^{43}$ (2017) stated that during the tissue healing process, fibroblasts are activated, then cell migration and proliferation occur.

The mean number of fibroblasts between Group I and Group II was significantly different. Fewer fibroblasts were detected in Group I than those detected in Group II. Application of CPPACFP prior to in-office bleaching results in closure of the dentinal tubules due to fluorapatite deposits. The decreased permeability of the dentinal tubules results in the incoming irritant (hydrogen peroxide and the product) being inhibited. This is in line with the research of Parreiras et al. ${ }^{44}$ (2020) stated that materials such as fluoride, nano calcium phosphate, and CPP-ACP products can act as physical barriers that reduce the entry of hydrogen peroxide to the pulp. Fewer hydrogen peroxide was detected in the pulp when desensitizing agents were applied prior to in-office bleaching.

Between Group I and Group III, and also between Group II and Group III the mean number of fibroblasts was significantly different. The application of CPP-ACFP before in-office bleaching in Groups I and III was shown to be effective in reducing the irritants introduced by partially closing the dentinal tubules by mineral precipitates when compared to Group II. The lower dentin permeability causes chemical irritants and the product is less ROS so that the proliferation and migration of fibroblasts to the injured area is less. In Group I, it was seen that the mean number 
of fibroblasts detected was less than in Group II, and in Group III the number of fibroblasts was less than in Group I. This is in line with the statement of Ortiz et al. ${ }^{41}$ (2019) that CPP-ACFP can partially cover the dentinal tubules by depositing calcium, phosphate, and fluoride ions with high concentrations. The application of CPP-ACFP before bleaching did not affect the treatment outcome, this is supported by the statement of Parreiras et al. ${ }^{44}$ (2020) stated that the application of a desensitizing agent before bleaching did not affect the bleaching efficacy as measured by using a spectrophotometer.

In Group III, the desensitizing agent was applied twice, namely before and after bleaching the least number of fibroblasts detected, this was because the ROS that diffused into the pulp was not as much as in the other groups. The application of CPP-ACFP before the application of bleaching caused a decrease in dentin permeability due to partial closure of the dentinal tubules by fluorapatite precipitates, and the application of CPP-ACFP after the bleaching application made the mineral precipitates more stable. Berkathullah et al. ${ }^{45}$ (2018) stated that it takes the application of CPP-ACFP more than once to form stable mineral precipitates in the dentinal tubules. Scanning Electron Microscope (SEM) image of the dentinal tubules shortly after CPP-ACFP application shows the presence of mineral precipitates that partially cover the dentinal tubules with a cobblestone-like appearance. The research of Berkathullah et al. ${ }^{45}$ (2018) also mentioned that after the dentin disc was immersed in artificial saliva for 7 days, SEM images showed that some of the deposits had detached from the dentinal tubules. Pinto et al. ${ }^{46}$ (2010) stated that the repeated application of a desensitizing agent could increase its clinical effectiveness.
Between Control Group and Group II, the mean number of fibroblasts between the two groups did not differ significantly. This occurs because the bleaching agent in the form of hydrogen peroxide and its oxidation products have penetrated first through the interprismatic space of the enamel and dentinal tubules into the pulp, resulting in injury to the pulp tissue, this condition results in the number of fibroblasts detected in this group not much different from the number of fibroblasts in the Control Group. This is supported by Silva-Costa et al. $^{2}$ (2018) who stated that the pulp response to bleaching varies from mild to severe inflammatory reactions that can even cause partial necrosis of the coronal pulp tissue. Inflammatory reactions due to oxidative stress caused by ROS can still occur even though the composition of the bleaching gel contains desensitizing agents, namely potassium nitrate and fluoride because hydrogen peroxide has a lower molecular weight so that hydrogen peroxide reaches the pulp more quickly and causes injury and causes an inflammatory response ${ }^{5}$.

\section{CONCLUSION}

Based on the results, it can be concluded that the application of desensitizing agent before and after bleaching causes the number of fibroblasts in the dental pulp after bleaching with $40 \%$ hydrogen peroxide to be less than the application of a desensitizing agent before or after bleaching with $40 \%$ hydrogen peroxide. Another conclusion is the application of desensitizing agent before bleaching causes the number of fibroblasts in the tooth pulp after bleaching with $40 \%$ hydrogen peroxide less than the application of a desensitizing agent after bleaching with $40 \%$ hydrogen peroxide.

\section{ACKNOWLEDGEMENT}

This research was funded by the Ministry of Health of the Republic of Indonesia. 


\section{REFERENCES}

1. Cartagena, A.F., Parreiras, S.O., Loguercio, A.D., Reis, A., Campanha, N.H. In-office bleaching effects on the pulp flow and tooth sensitivity - case series. Braz. Oral Res. 2015;29(1): 1-6

2. Silva-Costa, R.S.G., Ribeiro, A.E.L., Assuncao, I.V., Araujo Junior, R.F., Araujo, A.A., Guerra, G.C.B., Borges, B.C.D. In-office tooth bleaching with $38 \%$ hydrogen peroxide promotes moderate/severe pulp inflammation and production of II-1 $\beta$, TNF- $\beta$, GPX, FGF-2 and osteocalcin in rats. JAOS. 2018;26: 1-9

3. Sato, C., Rodrigues, F.A., Garcia1, D.M., Vidal, C.M.P., Pashley, D.H., Tjäderhane, L., Carrilho, M.R., Nascimento, F.D., Tersariol, I.L.S. Tooth Bleaching Increases Dentinal Protease Activity. J Dent Res. 2013;92(2): 187-192

4. Alqahtani, M. Q. Tooth Bleaching Procedures and Their Controversial Effects: A Literature Review. The Saudi Dental Journal, 2014;26: 33-46

5. Maran, B.M., Vochikovski, L., Hortkoff, D.R.A., Stanislawczuk, R., Loguercio, A.D., Reis, A. Tooth sensitivity with a desensitizing containing at-home bleaching gel - a randomized triple-blind clinical trial. Journal of Dentistry. 2018;72: 64-70

6. Akbari, M., Nejat, A.H., Farkhondeh, N., Moghadam, S.M., Mohammadipour, H.S. Does at-home bleaching induce systemic oxidative stress in healthy subjects. Australian Dental Journal. 2017;62: 58-64

7. Abutalib, A.M., Fensa, H. Evaluation of the Human Enamel Surface Morphology after Tooth Bleaching Followed by Remineralizing Agents. IHJSR. 2017;7(3) : 181-189

8. Pashley, D.H. Dentin Permeability, Dentin Sensitivity, and Treatment Through Tubule Occlusion. JOE. 1986;12(10): 465-474

9. Arrais, C.A.G., Chan, D.C.N., Giannini, M. Effects Of Desensitizing Agents On Dentinal Tubule Occlusion. J Appl Oral Sci. 2004;12(2): 144-8

10. Torres, C.R.G., Silva, T.M., Fonseca, B.M., Sales, A.L.L.S., Holleben, P., Di Nicolo, R., Borges, A.B. The Effect of Three Desensitizing Agents on Dentin Hypersensitivity: $A$ Randomized, Split-mouth Clinical Trial. Operative Dentistry. 2014;39(5) : E186-E194

11. Davari, A.R., Ataei E., Assarzadeh, H. Dentin Hypersensitivity: Etiology, Diagnosis, and Treatment; A Literature Review. J. Dent. Shiraz Univ. Med. Sci. 2013;14(3):136-45

12. Vanichvatana, S., Auychai, P. Efficacy of Two Calsium Phosphate Pastes on The Reminealization of Artificial Caries: $A$
Randomized Controlled Double- Blind in Situ Study. International Journal of Oral Science. 2013;5, 224-228

13. Banomyong, D., Kanchanasantikul, P., and Rebecca, HW. Effects of casein phosphopeptide - amorphous calcium phosphate remineralizing paste and $8 \%$ arginine desensitizing paste on dentin permeability. Journal of Investigative and Clinical Dentistry. 2013;4: 200-206

14. Kristanti, Y., Asmara, W., Sunarintyas, S., and Juni $\mathrm{H}$. Efektivitas Desensitizing Agent dengan dan tanpa Fluor pada Metode in Office Bleaching terhadap Kandungan Mineral Gigi (Kajian In Vitro). Maj Ked Gi. 2014; 21(2): 136 $-140$

15. Staquet, M.J., Durand, S.H., Colomb, E., Romeas, A., Vincent, C., Bleicher, F., Lebecque, S., Farges, J.C. Different Roles of Odontoblasts and Fibroblasts in Immunity. J Dent Res. 2008;87(3): 256-261

16. Dewanti, I.D.A.R., Susilawati, I.D.A., Lestari, P.E., Yani, R.W.E., Wulandari, E., Budirahardjo, R., Setyorini, D., Wibisono, S. Robusta Coffee (Coffeacanephora)

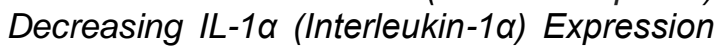
and Increasing the Number of Fibroblasts in Healing Process in Dental Pulp in Wistar Rats. J. Math. Fund. Sci. 2019;51(1): 68-76

17. Jeanneau, C., Lundy, F.T., El Karim, I., About, I. Potential Therapeutic Strategy of Targeting Pulp Fibroblasts in Dentin-Pulp Regeneration. JOE. 2017;43(95): S17-S24

18. Kunarti, S. TGF- $\beta 1$ As The Trigger Of Pulp Fibroblast Proliferation. Folia Medica Indonesiana. 2008;44(2):67-70

19. Mescher, A. L. Junquiera's Basic Histology Text and Atlas. 14 $4^{\text {th }}$ Ed., McGraw Hill Education. New York. 2016;97-100

20. Nakanishi, T., Takegawa, D., Hirao, K., Takahashi, K., Yumoto, H., Matsuo, T. Roles of dental pulp fibroblasts in the recognition of bacterium-related factors and subsequent development of pulpitis. Japanese Dental Science Review. 2011;47:161-166

21. Han, N., Zheng, Y., Li, R., Li, X., Zhou, M., Niu, Y., Zhang, Q. $\beta$-Catenin Enhances Odontoblastic Differentiation of Dental Pulp Cells through Activation of Runx2. PLOS ONE. 2014;9(2):1-11

22. Shah, A. Desensitizing Agents: A Review. Medical \& Clinical Review. 2017;3(3): 1-3

23. Oki, A.Q., Bimarahmanda, M.E., Rahardjo, M.B. Increased Number of Fibroblasts and Neovascularization after Tooth Extraction in Wistar Rats with Moderate-Intensity Continuous Exercise. Journal of International Dental and Medical Research. 2018;11(3): 840-845 
24. Natalia, D., 2018, Pengaruh Aplikasi Desensitizing Agent terhadap Jumlah Pembuluh Darah pada Pulpa Gigi pada Perawatan Bleaching Ekstrakoronal dengan Hidrogen Peroksida 40\% (Kajian In vivo pada Tikus Wistar), Thesis, Program pendidikan Dokter Gigi Spesialis Fakultas Kedokteran Gigi Universitas Gadjah Mada Yogyakarta

25. Sabir, A. Respons inflamasi pada pulpa gigi tikus setelah aplikasi ekstrak etanol propolis (EEP). Maj. Ked. Gigi. (Dent. J.). 2005;38(2): 77-83

26. Cintra, L. T. A., Benetti, F., Ferreira, L. L., Rahal, V., Ervolino, E., Jacinto, R. D., Filho, J. E. G. and Briso, A. L. F. Evaluation of an Experimental Rat Model for Comparative Studies of Bleaching Agents. J Appl Oral Sci. 2016;24 (1): 95-104

27. Fitria, L., Sarto, M. Profil Hematologi Tikus (Rattus norvegicus Berkenhout, 1769) Galur Wistar Jantan dan Betina Umur 4, 6, dan 8 Minggu. Biogenesis. 2014;2(2): 94-100

28. Dammaschke, T. Rat molar teeth as a study model for direct pulp capping research in dentistry. Laboratory Animal.2010;44: 1-6

29. Pribadi, H.A., 2017, Pengaruh Bahan Antioksidan Sodium Askorbat 10\% dan 25\% terhadap Jumlah Pembuluh Darah Pulpa pada Gigi Tikus Pasca Bleaching Ekstrakoronal dengan Hidrogen Peroksida 40\%, Thesis, Program Pendidikan Dokter Gigi Spesialis Fakultas Kedokteran Gigi Universitas Gadjah Mada Yogyakarta

30. Hargreaves, K.M., Berman, L.H. Cohen's Pathway of the Pulp, $11^{\text {th }}$ Ed., Elsevier, Missouri, 2016; 537-538, 590-591, 644, e-100

31. Addis, R., Cruciani. S., Santaniello, S., Bellu, E., Sarais, G., Ventura, C., Maioli, M., Pintore, P. Fibroblast Proliferation and Migration in Wound Healing by Phytochemicals: Evidence for a Novel Synergic Outcome. International Journal of Medical Sciences. 2020;17(8): 1030-1042

32. Vasconcelos, A.A.M., Gama Cunha, AA.G., Borges, B.C.D., Vitoriano, J.D., et al. Enamel properties after tooth bleaching with hydrogen/carbamide peroxides in association with a CPP-ACP paste. Acta Odontologica Scandinavica. 2012; 70: 337-343

33. Ghafournia, M., Tehrani, Nekouei, A., et al. In vitro evaluation of dentin tubule occlusion by three bioactive materials: A scanning electron microscopic study. Dental Research Journal. 2018;16(3):166-171

34. Martini, E.C., Parreiras, S.O., Szez, A.L. Bleaching-induced tooth sensitivity with application of a desensitizing gel before and after in-office bleaching: a triple-blind randomized clinical trial. Clinical Oral Investigations 2018;1-10. https://doi.org/10.1007/s00784-019-02942-9

35. Andriani, A., Handajani, J., Haniastuti, T. Pulpal inflammation after vital tooth bleaching with 38\% hydrogen Peroxide. Dent. J. (Maj. Ked. Gigi). 2012;45(2):89-92

36. Vaz, M., Lopez, LG., Cardoso, PC., Souza, JB., Batista, AC., Costa, NL., Torres, EM., Estrela, C. Inflammatory Response of Human Dental Pulp to At- Home and In Office Bleaching. J Appl Oral Sci. 2016;24(5): 509-17

37. Le Bras, M., Clement, M.V., Pervaiz, S., Brenner, C. Reactive oxygen species and the mitochondrial signaling pathway of cell death. Histol Histopathol. 2005;20: 205-220

38. Li, R. Jia, Z., Trush, M.A. Defining ROS in Biology and Medicine. React Oxyg Species (Apex). 2016;1(1): 9-21

39. Cintra, L.T.A., Benetti, F., Ferreora, L.L., Gomes-Filhp, J.E., Ervolino, E., Gallinari, M.O., Rahal, V., Briso, A.L.F. Penetration Capacity, Color Alteration and Biological Response of Two In-office Bleaching Protocols. Braz Dent J. 2016;27(2):169-175

40. Heshmat, H., Ganjkar, M.H., Miri, Y., Fard, M.J.K. The effect of two remineralizing agents and natural saliva on bleached enamel hardness. Dental Research Journal. 2015;13(1):52-27

41. Ortiz, M.I.G., Alencar, C.M., Paula B.L.F., dkk. Effect of the casein phosphopeptideamorphous calcium phosphate fluoride (CPPACPF) and photobiomodulation (PBM) on dental hypersensitivity: $A$ randomized controlled clinical trial. Plos One. 2019;1-14

42. Luschaks, V.I., , Free radicals, reactive oxygen species, oxidative stress and its classification. Chemico-Biological Interactions. 2014;224: 164-175

43. Goldberg, M., Hirata, A. The Dental Pulp: Composition, Properties and Functions. JSM Dent. 2017;5(1): $1079: 1-10$

44. Parreiras, S.O., Favoreto, M.W., Lenz, R.E., dkk. Effect of Prior Application of Desensitizing Agent on the Teeth Submitted to In-Office Bleaching. Braz Dent J. 2020;31(3):236-243

45. Berkathullah, M., Farook, M.S., Mahmoud, O. The Effectiveness of Remineralizing Agents on Dentinal Permeability. BioMed Research International. 2018;1-13

46. Pinto, S.C.S., Pochapski, M.T., Wambier, D.S., dkk. In vitro and in vivo analyses of the effects of desensitizing agents on dentin permeability and dentinal tubule occlusion. Journal of Oral Science. 2010;52(1):23-32 